\title{
Human Rights in the EU and the US: Social Worker v. Good Cop?
}

\author{
Frédéric Krumbein \\ Freie Universität Berlin, Berlin, Germany \\ Email: frederic.krumbein@swp-berlin.org
}

How to cite this paper: Krumbein, F. (2017). Human Rights in the EU and the US: Social Worker v. Good Cop? Open Journal of Political Science, 7, 101-115. http://dx.doi.org/10.4236/ojps.2017.71008

Received: November 23, 2016 Accepted: December 27, 2016 Published: December 30, 2016

Copyright $\odot 2017$ by author and Scientific Research Publishing Inc. This work is licensed under the Creative Commons Attribution International License (CC BY 4.0).

http://creativecommons.org/licenses/by/4.0/

\begin{abstract}
The EU and the United States are the most important state promoters of human rights and share a common human rights legacy. However, the human rights approaches of the EU and the US display crucial differences in comparison to each other: first, the acceptance of social and economic rights in Europe v. a focus on individual freedom in the US; second, a stricter and harsher law enforcement in the US; and third, the possibility for EU citizens to address international human rights courts and commissions. Values and attitudes explain the transatlantic divide in human rights. The EU emphasizes dignity as the core value underpinning human rights and is more reluctant towards the use of force inside and outside its borders. In the US, negative freedom is the paramount value for justifying human rights and the United States are more willing to use force against criminals, terror suspects and enemies abroad.
\end{abstract}

\section{Keywords}

Human Rights, European Union, United States of America, Human Dignity, Negative Freedom

\section{Introduction}

Europe and the United States of America share a common history and legacy in the field of human rights. Until today, human rights have been core values of both Europe and the US. Both are the most ardent promoters of these rights on the global stage (among state actors) and they both claim that they pursue an ethical foreign policy (Fogarty, 2013: 20f.). However, there is an important-and increasing-gap in their approach towards human rights. The following study explores these differences and tries to explain them. A comparative analysis of the two human rights understandings and their underlying values is missing.

To undertake a comparison of a large country like the US and a European Union of 28 states in the area of human rights cannot be exhaustive, but has to limit itself in scope and aim. Foremost, comparative evaluations are never absolutes and are always 
made in term of more or less. Generalizations also change, when the unit of comparison changes (Lipset, 1996: p. 32).

Furthermore, the comparison between the US and the EU reflects the contemporary world in the $21^{\text {st }}$ century. The last major shift in the US human rights approach took place after September 11, 2001, and the following US-led "war on terror". In the EU, the last major change occurred with the Lisbon Treaty that entered into force in 2009 and made the Charter of Fundamental Rights a legally binding document for the EU and its member states when applying European law. Important regional differences in the US and in the EU remain, too. Finally, the number of human rights, as well as of human rights abuses in the EU and the US, is too vast to report entirely. Some topics had to be selected to catch best the differences between the EU and the US.

Firstly, the official human rights positions will be compared, i.e. the human rights law enshrined in the EU Charter of Fundamental Rights and in the US Constitution. Secondly, the attitude of the EU and the US towards international human rights jurisdiction and law, particularly human rights courts and human rights commissions will be analysed. Thirdly, in order to highlight further differences, major areas of concern in the human rights situation of both actors will be compared. The annual reports of the two major human rights organizations, Amnesty International and Human Rights Watch, for the last ten years provide the empirical basis for this comparison. The most frequent topics in the annual reports that are reported every year in both the EU and the US are counterterrorism, migrants' rights, discrimination, and ill-treatment or the use of excessive force and coercion in law enforcement. For the US, the annual reports of both organizations also highlight in every year the death penalty and other excessive or cruel punishments. The study will focus on counterterrorism, the use of excessive force and coercion in law enforcement, and excessive or cruel punishments. These areas display the most important differences between the EU and the US and to cover sufficiently well the topics of migrants' rights and discrimination would exceed the scope of this study. The study will thus compare these areas in order to highlight differences (Amnesty International, 2006-2015; Human Rights Watch, 2006-2015).

The first chapter will compare human rights in the EU and the US and identify four differences in subsequent sections: a broad European human rights conception v. a narrower American one; the promotion and respect of international human rights law by European states v. American emphasis on sovereignty; a stricter and harsher law enforcement in the US than in the EU; and more severe human rights violations in the fight against terrorism by the United States. The second chapter argues that different sources of human rights in the European Union (dignity) and the US (negative freedom) and "violence exceptionalism" and moral absolutism in the case of the United States in comparison to a soft power approach and moral relativism in the EU may explain the four identified differences in the area of human rights.

\section{Comparison of Human Rights in the EU and the US}

\subsection{Broad European Human Rights Conception v. American Focus on Individual Freedom}

Human rights are among the core values of the European Union, even if they were not 
part of the founding values (Smismans, 2010: 46f.). They are now explicitly mentioned in article 2 of the Treaty of the European Union: "The Union is founded on the values of respect for human dignity, freedom, democracy, equality, the rule of law and respect for human rights, including the rights of persons belonging to minorities." (TEU, 2012: article 2) The promotion of human rights is also an objective of the EU's foreign relations (TEU, 2012: article 3 und 21).

Since the coming into force of the Lisbon Treaty in 2009, the Charter of Fundamental Rights became legally binding in EU law. The European Union also gained a legal personality, fulfilling a necessary condition to become a member of the European Convention on Human Rights (ECHR). The accession is currently in the process of negotiation between the EU and the Council of Europe.

The Charter of Fundamental Rights contains in 54 articles a vast amount of human rights. A first category encompasses the protection of the dignity, life, and mental and physical integrity of the person (articles $1-5$ ). A second category comprises the guarantee of individual freedoms, as the rights to privacy, data protection and marriage, the freedoms of thought, conscience, religion, expression, assembly, association, arts and sciences, the rights to education and to choose an occupation and conduct business, and the rights to property and asylum (articles 6 to 19). A third category enshrines equality of all human beings and non-discrimination (articles 20 to 26). The fourth category of human rights are the social and economic rights, as the rights to collective bargaining and action, to fair and just working conditions, to social security and health care, and to environmental and consumer protection (articles 27 - 38). Furthermore, the Charter protects as a fifth category the democratic rights of European citizens, as the rights to vote and to stand as a candidate at elections, to a good administration and to free access to documents, as well as the rights to petition and free movement in the EU (articles 39 - 46). The sixth category guarantees the right to a fair trial and a fair and just judicial system (articles 47 - 50). The articles 51 to 54 guide the application and limitation of the above-mentioned rights.

The Charter of Fundamental Rights shows that the European Union has a broad understanding of human rights, encompassing civil and political as well as economic, social and cultural human rights. Civil and political rights are mostly the rights contained in the International Covenant on Civil and Political Rights (ICCPR), associated with negative freedom, as freedoms of opinion, religion, assembly or association or the rights to life and a fair trial. Economic, social and cultural rights can be find in the International Covenant on Economic, Social and Cultural Rights (ICESCR), as for example the rights to education, social security, work, or an adequate living standard. Both covenants are the two major human rights treaties of the United Nations and formtogether with the Universal Declaration of Human Rights-the "International Bill of Human Rights". The EU possesses one of the most far-reaching and advanced human rights conceptions with the inclusion of the prohibition of discrimination on the ground of sexual discrimination, the right to a good and transparent administration, bioethical rights or data protection (EU, 2010).

The ratification practice of international human rights treaties of EU member states also underlies this broad understanding of human rights. All EU states have ratified the 
two major UN human rights treaties ICCPR and ICESCR. All member states of the European Union have also ratified the European Social Charter of 1965 and/or the revised European Social Charter of 1999 (Council of Europe, 2016; UN Treaty Collection, 2016). The European Union and its member states are among the strongest supporters of economic, social and cultural (ESC) rights in the world, both in rhetoric and implementation.

The United States has a long history of human rights, too. The Bill of Rights of 1789 as part of the US Constitution encompasses a catalogue of human rights. The ten original amendments to the constitution guarantee the rights to free speech, assembly, association and religion and the right to petition the government (first amendment), the security of the persons, their houses and their communications (fourth amendment), the right to a fair trial and "habeas corpus" (fifth to seventh amendments) and the prohibition of cruel and unusual punishment (and treatment) (eighth amendment). Later amendments prohibit slavery (thirteenth amendment, 1865), guarantee the right to life, freedom and property (fourteenth amendment, 1868) and open the right to vote for African-Americans, women, and people over the age of 18 (fifteenth, nineteenth, and twenty-sixth amendments from 1870, 1920, and 1971) (US Bill of Rights, 2016).

The acceptance of social and economic human rights by the EU marks a first difference in the definition of human rights in comparison to the US. The US is the state with most objections to this category of rights. The constitution does not include any ESC rights and the US has signed, but not ratified the ICESCR, and ratification is very unlikely. Even if the US has a lot of provisions that are similar to the European welfare states, the recognition of social and economic rights as legal obligations is not part of the current human rights position of the US (Alston/Goodman, 2013: pp. 292-294).

In general, the US tends to recognise fewer human rights whose purpose is to protect individual negative liberty against the state. In the EU, more rights are recognised and conflicting rights and the interests of society are taken more into account. Consequently, the individual person possesses more liberty in the US in some important domains, but sometimes at the expense of the rights of others. One important example of this is freedom of expression. Freedom of expression in the US is exceptional in its wide-ranging protection. In the US, "hate speech," i.e. speech that is commonly prohibited for reasons of its contribution to intolerance and discrimination, is allowed in most cases: "in the United States restrictions on the incitement of racial hatred can be countenanced under the First Amendment only when they are incitements to violent racial hatred, and even then only under the rare circumstances in which the incitements unmistakably call for immediate violent action, and even then only under the more rare still circumstances in which members of the listening audience are in fact likely immediately to act upon the speaker's suggestion." (Schauer, 2005: p. 36) In Europe, as in most other states worldwide, "hate speech" is prohibited (Schauer, 2005).

In sum, the EU member states advocate a broad array of human rights, particularly civil and political as well as social, economic, and cultural human rights. The US only recognizes civil and political human rights.

\subsection{US Sovereignty v. EU's Internationalism}

Another characteristic of the official EU's human rights position is the acceptance and 
promotion of international human rights justice. The member states of the European Union have all ratified the European Convention on Human Rights. The Convention establishes the European Court of Human Rights (ECtHR). The ECtHR interprets the ECHR and guarantees its provisions in the member states of the Council of Europe. The ECtHR is the highest court for citizens of the Council of Europe member states, among them all the member states of the EU, for judging human rights violations. The ECtHR was the first international human rights court, is the most judicially developed and has generated a more extensive jurisprudence than any other international human rights court. Citizens can only address the ECtHR after domestic remedies have been exhausted.

The vast majority of the member states of the EU have also ratified the six optional protocols of the ten core human rights treaties of the United Nations that allow citizens of the treaty states to file individual complaints about human rights violations, under the condition that they have exhausted all domestic remedies. The treaty bodies, consisting of individual experts, examine the individual complaints and give their advice to the person and the state concerned, but the advice is not a judgment and thus not legally binding for the state (Alston/Goodman, 2013: pp. 808-812, UN Treaty Collection, 2016).

The US accepts as human rights the rights of her constitution. This means that the US only ratifies human rights treaties that are in agreement with the US Constitution or that are limited to its provisions by reservations made by the US upon ratification of the human rights treaties (Ignatieff, 2005: p. 14). The result is that the US has ratified only a few of the core human rights treaties of the UN and is part of the minority of states that have, among others, not ratified the ICESCR, the Convention on the Rights of the Child and the Convention on the Elimination of All Forms of Discrimination Against Women (UN Treaty Collection, 2016).

The US also rejects all human rights treaties that would provide US citizens with the possibility to claim their rights in front of an international court or another international body. The US has neither ratified the American Convention on Human Rights nor one of the other eight regional human rights treaties and protocols. As a result, US citizens have no access to the Inter-American Court of Human Rights and the InterAmerican Commission on Human Rights (Alston/Goodman, 2013: pp. 980, 987). The US has also refrained from ratifying any of the UN optional protocols that introduce an individual complaint mechanism (UN Treaty Collection, 2016).

\subsection{Stricter and harsher law enforcement in the US than in the EU}

The US penal system is, in most aspects, harsher than the systems in EU member states. Two forms of harshness will be discussed to underline the differences between the US and the EU prison systems: harshness in the law of punishment, i.e. a light or severe punishment for offences, and harshness in the application of punishment, e.g. tough prison conditions (Whitman, 2003: pp. 33-35).

Firstly, in the United States, more people are convicted for longer periods than in Europe. The US is the country with the biggest population of prisoners, both in absolute and relative terms. The US incarcerates about 2.2 million people for about 312 million 
inhabitants. The countries of the European Union imprison only about 630,000 persons, and they have a population of more than 500 million people (Walmsley, 2013). The bigger prison population in the US reflects harsh sentencing regimes and a "toughon-crime" policy since the 1970s, such as the introduction of mandatory sentences and of longer prison sentences in general, or of reducing and abolishing parole (ACLU, 2013a: pp. 32-27; HRW, 2014: p. 642).

Secondly, the European Union refrains from some forms of punishments, because of the alleged breach of human rights. The most famous example is the death penalty, which does not exist in the countries of the European Union. It is forbidden under article 2 of the Charter of Fundamental Rights of the European Union and the additional protocols nos. 6 and 13 of the European Convention on Human Rights. In the US, capital punishment still exists under the jurisdiction of 32 states and the federal government. In 2015, 28 people were executed (Amnesty International, 2016: p. 13).

Another punishment is largely unknown in Europe: lifelong imprisonment. In the US, about 160,000 people serve life sentences, nearly 50,000 of them life sentences without the possibility of parole. More than 10,000 life-sentenced inmates have been convicted of crimes that occurred before they turned 18. More than 10,000 people have been convicted with a life sentence for non-violent crimes, with more than 3000 of them sentenced to life without parole (ACLU, 2013a: p. 2; Nellis, 2013: p. 1). In the European Union, lifelong imprisonment until one's real end of life is exceptional. Only the United Kingdom and the Netherlands still sentence people to life without the possibility of parole and it only applies to about fifty people, all convicted of serious violent crimes. Recent judgments of the European Court of Human Rights confirm the tendency in Europe towards the restriction of this punishment. The court states that lifelong imprisonment would be a violation of article 3 of the ECHR, if there are no penological grounds for a continued imprisonment and if the life sentence could not be reduced de facto and de jure. The court thus demands that there is an opportunity for review of the prisoners' life sentence, making lifelong imprisonment without the possibility of parole illegal (ACLU, 2013a: pp. 200-203; ECHR, 2013a: p. 34; Harris et al., 2009: 91f.; Nellis, 2013: 16f.).

Thirdly, besides much more severe punishments in general and the existence of other forms of punishments in the US, the conditions of imprisonment also differ. One important difference is the application of solitary confinement. Solitary confinement usually means the practice of placing a prisoner alone in a cell for $22-24$ hours a day, with little human contact or interaction, severe limits on visitation and the inability to participate in group activities. In the US, at least 80,000 prisoners are in solitary confinement every day, some of them for years. This causes psychological problems to the prisoners, such as severe and chronic depression, self-mutilation, or decreased brain function. Thousands of juvenile detainees are also held in solitary confinement every day, sometimes only for a few hours, sometimes for much longer periods. For young people, solitary confinement is even more harmful than for adults (ACLU, 2013b; ACLU, 2013c: pp. 3-7).

In the European Union, solitary confinement is not per se forbidden. But the European Court of Human Rights forbids the complete sensory isolation of a prisoner, and a 
long period of solitary confinement is undesirable. The Court distinguishes between absolute sensory and social isolation and removal from association with other prisoners. The latter case normally does not amount to a violation of the European Convention, because social contact with prison and medical officers, lawyers and relatives and contact with the outside world through newspapers, radio and television is still possible. Nevertheless, in each case of solitary confinement the stringency of the measures, its duration, the objectives pursued and its physical and mental effects on the person concerned have to be taken into account (Harris et al., 2009: 95f.; van Dijk et al., 2006: 421f.; Mowbray, 2012: 184f.).

The right to privacy is also respected more in the states of the European Union. It is, for example, common in the United States to keep inmates in cells with barred doors, through which they are exposed to the view of guards and other inmates. In Europe, this practice was largely abandoned (Whitman, 2003: 64f.).

Fourthly, the differences in the punishment and treatment of prisoners between the states of the European Union and the United States are also reflected in the rights of prisoners to vote. In some member states of the European Union, all prisoners have the right to vote, e.g. Denmark, Ireland, the Netherlands, Spain and Sweden, and in others, such as Germany, France or Italy, most prisoners, depending on the crime committed, retain the right to vote (Katzenstein et al., 2010: p. 1050). The European Court of Human Rights forbids a general, automatic and indiscriminate disenfranchisement of all serving prisoners (ECHR, 2013b).

However, in the United States, all but two small states (Maine and Vermont) disenfranchise prisoners (Katzenstein et al., 2010: p. 1036). But even more problematic, from a European human rights perspective, is the disenfranchisement of former prisoners in the US. Two states disenfranchise for life all people ever convicted of felonies, eight other states impose lifetime bans for many categories of convictions, and 35 states bar anyone released on probation or parole. This means that more than five million Americans cannot vote due to disenfranchisement resulting from a current or past conviction. Minorities are disproportionately affected, i.e. 13 percent of African American men cannot vote in the US (Katzenstein et al., 2010: pp. 1036, 1040).

However, in the US there exists an, albeit slow, trend towards the incarceration of less people, as the prison population has continued to decline moderately in the last three years (Carson/Golinelli, 2013). The same is true for capital punishment. There is a trend against the use of the death penalty, with a decline in executions. Since 2007, five states have abolished the death penalty, amounting to a total of 18 abolitionist states. Three others imposed a moratorium (Amnesty International, 2016: p. 14).

Still, the relatively respectful and humane treatment of prisoners can be portrayed as one of the EU's characteristics in the area of human rights: "Like the opposition to the death penalty, European prison law and policy based on fundamental human rights principles have become part of a wider European cultural heritage." (van Zyl Smit \& Snacken, 2009: p. 384)

\subsection{Human Rights Violations in the Fight against Terrorism}

Three serious violations of human rights can be identified that the United States com- 
mitted since September 11, 2001 which distinguish it from EU practice: torture, arbitrary rendition and detention, and targeted killings. The EU and its member states are clearly not innocent of human rights violations, as in the case of data surveillance or the extradition of terror suspects to human rights violating countries, but the US approach was, as already described in the case of prisoners, more severe. A terror suspect has to fear a more serious violation of his or her human rights by the US than by EU states.

After September 11, the US started a "war against terror", which is largely waged outside the US and against alien citizens. From a legal perspective, if a state chooses to fight terrorism outside its borders, at least the law of war and humanitarian law are to be respected. The obligations to respect human rights differ from peacetime. But the US did neither fully respect the obligations of humanitarian law nor the obligations of international human rights law. This resulted in the denial of basic rights to terror suspects.

For some years, namely from 2002 to 2004, the US government allowed the torture of terror suspects and tortured a few dozens to perhaps a few hundred persons. A very narrow interpretation of the definition of torture in US law during this period allowed the use of torture, such as waterboarding (Luban, 2005: pp. 1452-1460). Only the Obama administration ended this practice and subjected all interrogations to techniques in accordance with international humanitarian and human rights law (Alston/ Goodman, 2013: 275f.).

The second case involves the denial of "habeas corpus" by the United States. President Obama closed all of the Central Intelligence Agency's (CIA) secret overseas detention centres and still intends to close the prison camp at Guantanamo Bay (Alston/ Goodman, 2013: p. 275). In January 2002, the administration of President George W. Bush had opened a prison camp at Guantanamo Bay, a US territory on Cuba, to incarcerate terror suspects. Nearly 800 prisoners were imprisoned at Guantanamo Bay, and less than 60 persons continue to be in custody at this site. Despite judgments of the US Supreme Court that granted the imprisoned persons some rights, they are largely denied their right to a fair trial over their detention and, even more importantly, their liberty (Alston/Goodman 2013: 475f.; ACLU, 2014).

In the states of the European Union, only the United Kingdom detained 17 foreign nationals after September 11, 2001 without due process. The foreign nationals could not be deported to their home countries due to the fear of ill-treatment, but were seen as a security risk to the UK. Both the UK's highest court at that time, the House of Lords, and the European Court of Human Rights, held that the measures were incompatible with the European Convention on Human Rights (Alston/Goodman, 2013: pp. 432-443).

The third crucial difference in combating terrorism lies in the use of targeted killings: "A targeted killing is the intentional, premeditated and deliberate use of lethal force, by States or their agents acting under colour of law, or by an organized armed group in armed conflict, against a specific individual who is not in the physical custody of the perpetrator.” (UN Human Rights Council, 2010: p. 3)

The United States uses mainly unmanned drones to conduct targeted killings. Drone strikes started in the year 2002, and up to 2013 the US think tank New America Foun- 
dation estimates that between 2003 and 3321 persons were killed in Pakistan, plus between 427 and 679 in Yemen (Rudolf, 2013: p. 5). Such targeted killing under humanitarian law "is only lawful when the target is a "combatant" or "fighter" or, in the case of a civilian, only for such time as the person 'directly participates in hostilities.' In addition, the killing must be militarily necessary, the use of force must be proportionate so that any anticipated military advantage is considered in light of the expected harm to civilians in the vicinity, and everything feasible must be done to prevent mistakes and minimize harm to civilians." (UN Human Rights Council, 2010: p. 10)

The state in which the targeted killing takes place must also permit the killing, or the perpetrator must act in self-defence. The legality of targeted killings by the US in Afghanistan, Pakistan and Yemen in the combat against terrorism is highly controversial. It depends on how far the criteria mentioned are fulfilled, and with regard to this question international jurists did not reach a consensus. These questions should not be further explored. But in comparison, the European Union member states disapprove the use of this instrument, mainly due to doubts about its legality under international law.

\section{Discussion}

The following two parts argue that the sources of human rights in the EU and the US (dignity v. negative freedom) and the attitude towards violence and moral judgment may explain some of the above-mentioned differences.

\subsection{Dignity v. Negative freedom}

Nowadays, dignity can be seen as a universal status that every single human being possesses: “..., human dignity should be seen as an expression that signifies a status which other human beings and political institutions have to respect. This respect can be interpreted primarily in a sense of moral obligations or-as happened in the twentieth century-in the sense of individual rights that can be legally enforced. ...This concept of "human dignity" is universal: it signifies a status that cannot be lost, and thus may provide a foundation of rights." (Düwell, 2014: p. 27)

Marcus Düwell distinguishes different conceptual relationships between human rights and dignity. One of these relationships views dignity as an overarching principle that guides the interpretation of the entire set of human rights and has a unique status as the primary source of moral and legal obligations (Düwell, 2014: 29f.). Dignity has become this overarching principle in the European Union, whereas in the US this overarching principle is negative freedom. This is despite its validity in my opinion a farreaching and partly oversimplified understanding of the conception of human rights in Europe and the US. Other principles, as equality or privacy, as well as freedom in the EU and dignity in the US, also play important roles for the foundation and interpretation of human rights.

The EU Charter of Fundamental Rights protects human dignity in its article 1, reflecting the German Basic Law of 1949 and the UDHR of 1948, and the Charter stresses the paramount importance of this value (Borowsky, 2014). The official explanation to the Charter emphasizes that dignity is the fundament of all human rights, reflecting itself the preamble of the UDHR. "The dignity of the human person is not only a funda- 
mental right in itself but constitutes the real basis of fundamental rights." (Official Journal of the European Union, 2007: p. 17)

The European Convention on Human Rights does not explicitly refer or rely on the notion of human dignity, but it implies the respect for human dignity. The jurisprudence of the ECtHR recognizes that human dignity is implicated in the ECHR's protection of human rights, as for example one judgment from 2002 (Pretty v. United Kingdom) affirms: "the very essence of the [Convention] is respect for human dignity and human freedom." (Borowsky, 2014: p. 115; Brownsword, 2014: p. 5) The decisions of the European Court of Justice also reflect the importance of the principle of dignity in European law (Borowsky, 2014: p. 107). The role and importance of the principle in dignity in EU member states laws differ, but most of the member states' constitutions mention dignity. Dignity is frequently related to the physical and mental integrity of the person and to social rights. The discussions in the Convention that drafted the Charter of Fundamental Rights referred as well mostly to these two categories of human rights in relation to human dignity (Borowsky, 2014: pp. 107-119).

While dignity is frequently invoked in US American law, it has not the same importance as in the European Union: "As a legal concept, it [human dignity] has had a limited direct impact. It has not, for example, been recognized by the Supreme Court as a constitutionally protected interest to the degree that liberty, equality, or even privacy have. It has not been enshrined in positive law as a doctrinal principle directly applicable to regulate conduct. It is, however, often invoked by courts and officials in the political branches alike to amplify the moral claims made pursuant to more commonly recognized principles of American law, such as equality, liberty, privacy and justice." (Snead, 2014: p. 393) In general, the constitutional and judicial tradition of the United States has been consistently more critical of government, more insistent on individual responsibility and on individual freedom than the European traditions (Ignatieff, 2005: p. 11).

But dignity does not only play a more important role in European law than in US law: The understanding of dignity is also a different one. Courts in the US frequently interpret dignity as the right to a certain degree of individual autonomy, a space for freedom of action without interference by the state, "dignity rests in individual agency, the ability to choose without state interference" (Rao, 2011: 203f.).

Dignity in the European understanding is in most cases not related to negative individual freedom and autonomy as in the US (Rao, 2011: p. 217). The primary source of dignity in Europe stems from community values and respect, not from personal autonomy (Rao, 2011: p. 220). Dignity in Europe reflects a conception of a dignified human person. This includes valuable forms of human behavior and morality. It also includes a certain minimum standard of living, as a life in dignity is associated with positive social and economic goods (Rao, 2011: pp. 222, 235-242).

On the one hand, this (European) interpretation of dignity can lead to a paternalistic approach that restrains individual liberty. Court rulings in Germany, France, and the United Kingdom that have forbidden (against the wishes of the persons conducting these practices) mechanical peep-shows, dwarf-throwing and sexual sado-masochistic practices resulting in assaults and wounds are examples in which dignity trumps indi- 
vidual freedom and choice. However, this approach is not uniquely European, as US courts may also invoke dignity for the same reasons, but they seldom do so (Brownsword, 2014: pp. 10-18; Rao, 2011: pp. 221-234). The human rights granted in the US thus often encompass broader freedom and autonomy to act for the individual, as for example broad freedoms of expression or religion.

On the other hand, the emphasis on dignity in the EU and the understanding of dignity as a fundamental respect for the human person explains why ESC rights, a more humane treatment of prisoners and of terror suspects are an essential part of the European conception of human rights. James Whitman already emphasised that dignity and respect play an important role in the protection of prisoners' rights in Europe (Whitman, 2003: pp. 69-95).

Whitman also underlined a crucial point with the differentiation between the person and the act of a person: "Europeans simply perceive the legal world differently from Americans. They tend to perceive it as a world in which it is always right and proper to judge persons, and not only acts, and as a world in which it is imperative to maintain the dignity of persons, even when they have been convicted of criminal offenses." (Whitman, 2003: p. 95) Dignity resides in the person itself. The action resides in the autonomy and freedom of a person to act. The value of dignity puts the person in its centre and these results in safeguarding the fundamental human rights of the person regardless of its acts. The value of negative freedom emphasizes the liberty of every person to act with the less possible constraints, but also to take responsibility for its actions and to bear the consequences, if the actions violate the law and the freedom of others. For example, in the case of the rights of prisoners to vote, US courts have invoked contract theory to justify the deprivation of these rights. The core argument states that, if somebody violates the social contract by committing a crime and abusing the liberty given to him or her, he or she loses the right to further participate in this contract and his or her liberty (Katzenstein et al., 2010: pp. 1041-1045).

\subsection{Violence Exceptionalism and Moral Absolutism v. Soft Power and Moral Relativism}

A second explanation for the human rights conceptions and policies in the EU and the US stems from the use of violence and the moral perspective.

Firstly, the United States are a much more violent society than European ones. This "violent exceptionalism" is reflected in higher rates of violent crime, homicide and gun ownership. To treat gun ownership as a core constitutional right, as in the Second Amendment of the US constitution, is also exceptional (Weisberg, 2002). Scholars and journalists discuss different reasons for that high level of violence, as the Frontier mindset, a more vigilante and vengeful attitude, the conflicts over race and slavery or the most purely capitalist society. But they are difficult, if not impossible, to proof (Weisberg, 2002: p. 20): “Americans' sense of exceptionalism is a motley collection of self-conceptions. We know for a fact that we are anomalously violent. ...American violence exceptionalism remains both an intellectual puzzle and a statistical minefield." (Weisberg, 2002: 50f.) Even if the reasons for a higher level of violence aren't fully clear and provable, we can at least say that a different attitude towards violence exists in the 
US in comparison to the European Union. This different attitude explains in part the US approach to human rights. If violence is more prevalent in society, then a tougher approach of the state in law enforcement, as described above, is necessary to cope with more violent citizens and/or is even wished for by a society with a more violent attitude, e.g. in favoring the death penalty as punishment. According to Robert Kagan, the EU and the US have a fundamentally different approach in international politics, too. The US is more eager to use force in international relations than the Europeans and reflects the US society that is more violent in general (Kagan, 2004: pp. 8, 43).

Secondly, the US perspective also seems to be more dualistic than the European one and tends to differentiate more explicitly between good and evil (Kagan, 2004: pp. 8, 11; Lipset, 1996: p. 20). The United States often portray their own identity as good and the identity of their enemies as evil (Hancock, 2007: pp. 16, 31; Lipset, 1996: p. 20). Americans tend to advocate moral absolutism in comparison to Europeans, who tend to make moral claims depending more on the circumstances and advocate moral relativism (Lipset, 1996: pp. 63-67). In the US-led "war on terror" the US government portrayed the identity of the United States in terms of democracy, human rights, and freedom. The enemies, i.e. the terrorist, were portrayed as people hating democracy, human rights, and freedom, even if statements of Bin Laden show that the reasons of attacking the US were different, e.g. the US support for feudal monarchies in the Middle East and for Israel (Hancock, 2007: pp. 100-106): “The war on terror has been presented as a principally moral battle in line with the message from the president [George W. Bush] that 'we fight against evil'." (Hancock, 2007: p. 100) The same discourse of portraying the enemy as evil forces were used by other presidents while justifying their wars (Hancock, 2007: pp. 153/154; Lipset, 1996: pp. 66/67).

In contrary, the Europeans have largely renounced the concept of politics based on hard (military) power and violence as the ultimate end of politics. This is the European lesson, drawn out of the ruins of the First and Second World Wars. The EU prefers diplomacy, negotiation and persuasion, trade and development aid as tools of its foreign policy (Kagan, 2004: pp. 65-71).

This European approach towards international politics is widely discussed and own categories were established for this approach. One of the most prominent categories is the idea of the European Union as a "normative power" (Manners, 2002). According to this concept, the EU possesses some distinct "normative" characteristics in comparison to other global actors. Firstly, the EU has a normative identity that comes from its treaty-based legal order, its hybrid character with national and supranational forms of government. Secondly, the EU has normative interests that are reflected in its promotion of universal values, as human rights. Thirdly, the EU obeys in most cases international law and behaves as a normative power. Fourthly, the EU acts in a normative way, seldom using military means and only sometimes economic pressure. Europe mainly uses civilian instruments, as persuasion, setting an example or economic assistance to pursue its objectives in its foreign relations (Diez, 2005: p. 617; Forsberg, 2011: pp. 1191-1195; Manners, 2002). As a result, the EU is embedded in international human rights law, is more respectful of international law in general and tries to influence the international human rights regime with own initiatives and by setting a positive example. 
These two divergent approaches towards violence inside the societies and in international politics offer a second explanation for a different human rights approach. A more Manichean thinking in the US amplifies this point. The US tends to portray the struggle against criminals, terrorists, and foreign enemies as a battle between good and evil. The categorization of these persons as evil and a high willingness to use force and violence leads to the described differences in the US human rights approach in comparison to the EU.

\section{Conclusion}

In a caricature of the American human rights approach, the US could be drawn as a "good cop" who has his own absolute standard of right and wrong based on negative freedom and with the willingness to enforce it, if necessary with the use of force. The EU would be portrayed as a "social worker", talking about dignity and social and economic rights for everybody and with a reluctant attitude towards the use force. However, both have skeletons in the closet as was shown above in some examples. For the US, a different attitude towards the use of force by the state and more respect for human dignity, understood as the guarantee for persons to live a life in dignity under any circumstances, would be crucial to reduce human rights violations. The EU should mostly concentrate on living up to its own values. Two main challenges are to combat widespread discrimination and to guarantee the rights of migrants.

\section{Acknowledgements}

I acknowledge support by the German Research Foundation and the Open Access Publication Funds of the Freie Universität Berlin.

\section{References}

Alston, P., \& Goodman, R. (2013). International Human Rights. Oxford: Oxford University Press.

American Civil Liberties Union (ACLU) (2013a). A Living Death: Life without Parole for NonViolent Offense.

https://www.aclu.org/sites/default/files/assets/111213a-lwop-complete-report.pdf

American Civil Liberties Union (ACLU) (2013b). End the Overuse of Solitary Confinement. https://www.aclu.org/files/pdfs/prison/20120411 solitary confinement two-pager.pdf

American Civil Liberties Union (ACLU) (2013c). Alone \& Afraid: Children Held in Solitary Confinement and Isolation in Juvenile Detention and Correctional Facilities. https://www.aclu.org/files/assets/Alone\%20and\%20Afraid\%20COMPLETE\%20FINAL.pdf

American Civil Liberties Union (ACLU) (2014). ACLU Statement on the 12th Anniversary of Guantánamo.

https://www.aclu.org/national-security/aclu-statement-12th-anniversary-guantanamo

Amnesty International (2006-2015). Annual Reports: The State of the World's Human Rights. www.amnesty.org

Amnesty International (2016). Death Sentences and Executions 2015. https://www.amnesty.org/en/documents/act50/3487/2016/en/

Borowsky, M. (2014). Titel I-Würde des Menschen. In: J. Meyer (Ed.), Charta der Grundrechte der Europäischen Union (pp. 94-217). Baden-Baden: Nomos-Verlag. 
Brownsword, R. (2014). Human Dignity from a Legal Perspective. In Düwell, M., Braarvig, J., Brownsword, R., \& Mieth, D. (Eds.), The Cambridge Handbook of Human Dignity-Interdisciplinary Perspectives (pp. 1-22). Cambridge: Cambridge University Press. https://doi.org/10.1017/CBO9780511979033.003

Carson, A., \& Golinelli, D. (2013). Prisoners in 2012-Advance Counts, Bureau of Justice Statistics. http://www.bjs.gov/index.cfm?ty=pbdetail\&iid $=4737$

Council of Europe (2016). Treaty Office. http://www.coe.int/en/web/conventions/

Diez, T. (2005). Constructing the Self and Changing Others: Reconsidering "Normative Power Europe”. Millennium-Journal of International Studies, 33, 613-636. https://doi.org/10.1177/03058298050330031701

Düwell, M. (2014). Human Dignity: Concepts, Discussions, Philosophical Perspectives. In: Düwell, M., Braarvig, J., Brownsword, R., \& Mieth, D. (Eds.), The Cambridge Handbook of Human Dignity-Interdisciplinary Perspectives (pp. 23-52). Cambridge: Cambridge University Press.

EU (2010). Charter of Fundamental Rights of the European Union. http://ec.europa.eu/justice/fundamental-rights/charter/index en.htm

European Court of Human Rights (ECHR) (2013a). Case of Vinter and Others v. the United Kingdom.

European Court of Human Rights (2013b). Factsheet Prisoners' Right to Vote. http://www.echr.coe.int/Documents/FS Prisoners vote ENG.pdf

Fogarty, E. (2013). States, Nonstate Actors, and Global Governance-Projecting Polities. New York, NY: Routledge.

Forsberg, T. (2011). Normative Power Europe, Once Again: A Conceptual Analysis of an Ideal Type. Journal of Common Market Studies, 49, 1183-1204. https://doi.org/10.1111/j.1468-5965.2011.02194.x

Hancock, J. (2007). Human Rights and US Foreign Policy. London: Routledge.

Harris, D., O’Boyle, M., Bates, E., \& Buckley, C. (2009). Law of the European Convention on Human Rights. Oxford: Oxford University Press.

Human Rights Watch (HRW) (2006-2015). World Reports 2006-2015. www.hrw.org

Ignatieff, M. (2005). Introduction: American Exceptionalism and Human Rights. In M. Ignatieff (Ed.), American Exceptionalism and Human Rights (pp. 1-26). Princeton, NJ: Princeton University Press.

Kagan, R. (2004). Of Paradise and Power: America and Europe in the New World Order. New York, NY: Vintage Books.

Katzenstein, M., Ibrahim, L., \& Rubin, K. (2010). The Dark Side of American Liberalism and Felony Disenfranchisement. Perspectives on Politics, 8, 1035-1054. https://doi.org/10.1017/S1537592710003178

Lipset, M. S. (1996). American Exceptionalism: A Double-Edged Sword. New York, NY: W.W. Norton \& Company.

Luban, D. (2005). Liberalism, Torture, and the Ticking Bomb. Virginia Law Review, 91, 1425-1461. https://doi.org/10.1017/cbo9780511511110.003

Manners, I. (2002). Normative Power Europe: A Contradiction in Terms? Journal of Common Market Studies, 40, 235-258. https://doi.org/10.1111/1468-5965.00353

Mowbray, A. (2012). Cases, Materials, and Commentary on the European Convention on Human Rights (3rd ed.). Oxford: Oxford University Press.

Nellis, A. (2013). Life Goes on: The Historic Rise in Life Sentences in America, The Sentencing Project. http://sentencingproject.org/doc/publications/inc Life\%20Goes\%20On\%202013.pdf 
Official Journal of the European Union (2007). Explanations Relating to the Charter of Fundamental Rights, 14 December, C303/02.

http://eur-lex.europa.eu/LexUriServ/LexUriServ.do?uri=OJ:C:2007:303:0017:0035:en:PDF

Rao, N. (2011). Three Concepts of Dignity in Constitutional Law. Notre Dame Law Review, 86, 183-271.

Rudolf, P. (2013). Präsident Obamas Drohnenkrieg. SWP-Aktuell 37/2013. http://www.swp-berlin.org/fileadmin/contents/products/aktuell/2013A37 rdf.pdf

Schauer, F. (2005). The Exceptional First Amendment. In M. Ignatieff (Ed.), American Exceptionalism and Human Rights (pp. 29-56). Princeton, NJ: Princeton University Press. https://doi.org/10.2139/ssrn.668543

Smismans, S. (2010). The European Union's Fundamental Rights Myth. Journal of Common Market Studies, 48, 45-66. https://doi.org/10.1111/j.1468-5965.2009.02041.x

Snead, C. (2014). Human Dignity in US Law. In M. Düwell, J. Braarvig, R. Brownsword, \& D. Mieth (Eds.), The Cambridge Handbook of Human Dignity-Interdisciplinary Perspectives (pp. 386-393). Cambridge: Cambridge University Press.

https://doi.org/10.1017/CBO9780511979033.046

Treaty on the European Union (TEU) (2012). http://eur-lex.europa.eu/LexUriServ/LexUriServ.do?uri=OJ:C:2012:326:FULL:EN:PDF

UN Human Rights Council (2010). Report of the Special Rapporteur on Extrajudicial, Summary, or Arbitrary Executions, Philip Alston, Addendum-Study on Targeted Killings', 28 May, A/HRC/14/24/Add.6.

UN Treaty Collection (2016). https://treaties.un.org

US Bill of Rights (2016). http://www.archives.gov/exhibits/charters/bill of rights.html

Van Dijk, P., van Hoof, F., Van Rijn, A., \& Zwaak, L. (2006). Theory and Practice of the European Convention on Human Rights. Antwerpen: Intersentia.

van Zyl Smit, D., \& Snacken, S (2009). Principles of European Prison Law and Policy-Penology and Human Rights. Oxford: Oxford University Press.

Walmsley, R. (2013). World Prison Population List (10th ed.). International Centre for Prison Studies. http://www.prisonstudies.org/world-prison-brief-data

Weisberg, R. (2002). Values, Violence, and the Second Amendment: American Character, Constitutionalism, and Crime. Houston Law Review, 39, 1-51.

https://doi.org/10.2139/ssrn.311082

Whitman, J. (2003). Harsh Justice-Criminal Punishment and the Widening Divide between America and Europe. Oxford: Oxford University Press. 
Submit or recommend next manuscript to SCIRP and we will provide best service for you:

Accepting pre-submission inquiries through Email, Facebook, LinkedIn, Twitter, etc. A wide selection of journals (inclusive of 9 subjects, more than 200 journals) Providing 24-hour high-quality service

User-friendly online submission system

Fair and swift peer-review system

Efficient typesetting and proofreading procedure

Display of the result of downloads and visits, as well as the number of cited articles Maximum dissemination of your research work

Submit your manuscript at: http://papersubmission.scirp.org/

Or contact ojps@scirp.org 